\title{
Impact of cash conversion cycle on cash holding - A study on FMCG sector
}

\author{
Somnath Das*
}

Assistant Professor in Commerce, Kazi Nazrul University, Asansol, West-Bengal, India

\begin{tabular}{l}
\hline C H R O N I C L E \\
\hline Article history: \\
Received June 5, 2015 \\
Received in revised format \\
August 162015 \\
Accepted November 22015 \\
Available online \\
November 52015 \\
\hline Keywords: \\
Cash conversion cycle \\
Cash holding \\
Liquidity \\
Profitability
\end{tabular}
A B S T R A C T

In today's environment, cash conversion cycle is randomly used as a measure of liquidity of the organizations. Cash conversion cycle is considered as the length of time between rawmaterials and collection of cash from debtors. It can be used as a benchmarking competitors or comparing companies. On the other hand, Cash holding is one of the most important financial decisions that a manager has to make in any organization. Some organizations hold more cash and some organizations hold less cash. In this study, we perform a survey to make a relationship between Cash Conversion Cycle and Cash Holding.

\section{Introduction}

\subsection{Cash Conversion Cycle:}

The term Cash Conversion Cycle can be considered a length of time between purchase of raw-materials and collection of cash from debtors. In liquidity management, Cash Conversion Cycle is an important parameter for measuring its efficiency. Cash Conversion Cycle of a company indicates the efficiency of managing working capital. Such measure can be used in benchmarking competitors or comparing companies. Cash Conversion Cycle is constructed by deducting the payable deferral period from the addition of inventory conversion period and receivable collection period. Accounting information of companies can be classified into two groups or fields. They are financial distress prediction and fundamental analysis. Financial distress prediction analysis can be performed with the help of various statistical techniques. With the help of such statistical techniques, firms are classified into one number of mutually exclusive groups. On the other hand, fundamental analysis tests those information which is important to the organization or key value driver, which produces the growth in corporate securities. Both concepts are very useful for the organization using working capital frequently.

\footnotetext{
* Corresponding author.

E-mail address: somnath211@yahoo.co.in (S. Das) 
Due to increasing utility of empirical research different models have been developed with more theoretical content for better understanding the results of empirical research. To strengthen the work, theoretical interpretation can be developed on the basis of various accounting ratios. Therefore, accounting ratios are very important not only from academic point of view but also from the professional stand point. These ratios provide not only valuable information about the quality of working capital, efficiency of management, cash generating ability of operations and short-term liquidity risk of a firm (Saccurato 1994; Stickney, 1993) but also about the operating efficiency level (Holstrom, 1994). From various ratios, turnover ratios are considered as the global financial performance index and turnover ratios are established in such a way so that it could be useful in prediction of future financial problems. Cash conversion cycle also depends on such turnover ratios. These time variables integrate the working capital with the cash conversion cycle.

Liquidity management deals with the management of current assets and liabilities. Its main objective is to meet current liabilities timely. Many firms take advantage of external financing due to the difficulty in paying its short-term debt. But it should be remembered that it is not easy to collect such external financing easily, particularly in case of small firms. The cost of such borrowing is another important factor in external financing. It is too expensive and it signifies the poor bottom line. Thus, efficient liquidity management of a company helps its long-term prosperity and healthy bottom lines, and more specifically to make it remain solvent.

Cash Conversion Cycle (CCC) (Moss \& Stine, 1993) is a useful technique, which can easily and quickly evaluate firms' liquidity. As stated earlier, it computes the time lag between cash payments for purchase of inventories and collection of debts from customers. Traditionally, some static balance sheet values such as current ratio and quick ratio were useful indicators of liquidity (Moss \& Stine, 1993). But in case of CCC, it is a dynamic measure of continuous liquidity management, which comprises both balance sheet and income statement data with time dimensions (Jose et. al., 1996).

An individual firm's CCC is helpful but from stand point of industry it is crucial for a company to evaluate its performance regarding CCC and evaluate opportunities for improvement because the length of CCC may differ from industry to industry. Therefore, selection of industry in which the company belongs is important. Cash Conversion Cycle is an important context of Working Capital Management (Keown et al., 2003; Bodie \& Merton, 2000). The Term CCC is used as a comprehensive measure of working capital because it considers the time gap between expenditure for the purchases of rawmaterials and collection from sale of finished goods (Padachi, 2006, p. 49). So firm's short term assets and liabilities in a daily management play important role for the success of the firm.

Many authors defined CCC in different ways. Cash cycle time is regarded as the number of days between the date, the firm must start to pay cash to its suppliers and the date it begins to receive cash from its customer (Bodie \& Merton, 2000, p. 89). The bigger the time gap between payment to suppliers and received from customer, the bigger the cash conversion cycle. It can be minimized if money are collected from debtors faster but there is a more delay in payment to creditors. Cash conversion cycle can also be calculated by the sum of days of sales outstanding (average collection period) and days of sales in inventory less days payables outstanding (Keown et al., 2003, p.109). We can easily determine the average collection periods, inventory turnover periods and days of payables outstanding from the accounting information or from the Balance Sheet.

Cash cycle, like cash conversion cycle, is the number of days that pass before we collect the cash from sales, measured from when we actually pay for the inventory (Jordan, 2003) and it is more conceptual figure. Another concept related to cash conversion cycle is Cash Gap. Cash Gap computes the length of time between actual cash expenditures on productive resources and actual cash receipts from the sale of products or services (Eljelly, 2004, p. 50). It is one of the easiest procedures to measure the cash movement of the company. 
Therefore, with the help of the above definitions we can construct the following equations

Cash Conversion Cycle $=$ Days of Sales pending + Days of Sales in Inventory- Day of payables pending.

In the above equation the three variables on which CCC dependent are discussed below.

Days of sales pending $=$ Accounts Receivables $/$ Sales $/ 365$

Days of sales in inventory $=$ Inventories / cost of goods sold / 365

Days of payables pending $=$ Accounts payables $/$ Cost of goods sold $/ 365$

For better understanding of Cash Conversion Cycle we can draw the following diagram

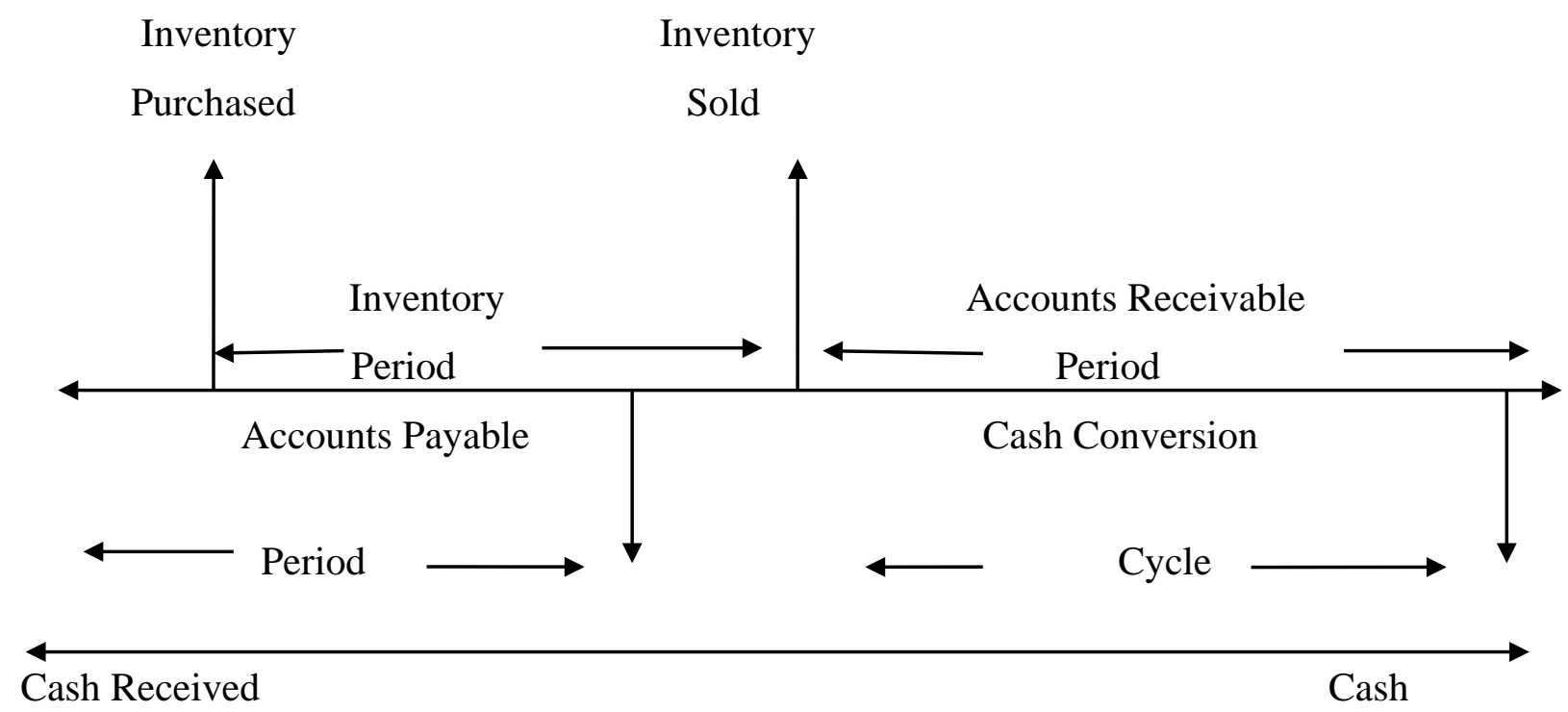

Fig. 1. Operating Cycle

Cash Conversion Cycle can be positive or negative. A positive Cash Conversion Cycle indicates that the number of days a company is borrowing is less than the period awaiting payment from a customer. On the other hand, negative CCC implies the number of days a company received cash from sales before it must pay its suppliers (Hutchison et al., 2007, p. 42). More impressive thing is that the goal of every company is to minimize its CCC, if possible negative. Because the shorter the CCC, the more efficient the company is in managing its cash flow. Therefore, from Fig., it is seen that a firm can reduce its need for working capital by (Bodie \& Merton, 2000, p. 90),

(a) Reducing the time included in inventory. This can be performed by improving the inventory control process or suppliers deliver the goods when the company needed for production.

(b) Collecting accounts receivable as early as possible. This can also be accomplished by improving the efficiency of the collection process, giving discounts to customers for faster collection and impose interest on accounts which are due for long period.

(c) Payment to creditors more slowly. This can be accomplished by improving relationship with creditors or suppliers.

Richards and Laughlin (1980) developed an equation comprising three policies, such as average receivables collection period (ARCP), average conversion inventory period (ACI) and average payment period (APP). They focused on the length of time between firm's cash inflow and outflow. Generally, a lower cash conversion cycle gives freedom to the manager to minimize the holdings of unproductive but valuable assets like cash and marketable securities, maintain the firm's debt capacity since less 
short term borrowings is needed to provide liquidity and this leads to bigger present value of net cash flows from firms assets (Jose et al., 1996). Cash Conversion Cycle is used by the financial managers of firm to diagnose why and when the firm requires more Cash for smooth running of its activities and how it will repay the cash (Özbayrak \& Akgün, 2006). On the basis of such policy, the firm tries to manage its policies by reducing the cash conversion cycle as much as possible without affecting its operation process and this will lead to increase the profits of the firm. In other words, when working capital is not managed properly, more funds is invested in it and the management is termed as nonefficient, which will reduce the benefit of short term investments(Chiou et al., 2006).

\subsection{Cash Holding}

Cash holding is one of the most important financial decisions that the manager of the concern organization, has to make in the organization. Some organizations hold more cash and some organizations hold less cash. But how much to hold is the primary question. For this different policies are framed. These policies have been regarded as the most important financial policies in the process of managing companies. Suppose, if we are in the world of Modigliani Miller then holding large amounts is irrelevant because the organizations can easily collect funds from money markets or capital markets for their profitable investment projects at a very negligible transaction costs. As mentioned earlier, cash holding is an important decision, a financial manager has to make. At the time of inflow of cash the manager may think whether it is distributed to the shareholder as dividend or purchase the shares from market or keep it for future purposes. Generally, it is seen that the organization hold cash for future purposes is very negligible. During 1990-2003 the average level of cash in U.S firms was 22\% (Dittmar \& Mahrt-Smith, 2007). Cash holding may be good if the firm invests it in any profitable securities (Keynes, 1936) or on the contrary there may be agency problem (Jensen, 1986). So in case of investment in profitable securities cash gives some flexibility but when it relates to the capital market holding cash is not advantageous.

However, many international studies show that holding of cash is important for its growth. For example, Kalcheva and Lins (2003), find that companies hold on an average of their total assets in cash or cash equivalents, Ferreira and Vilela (2004) find an average cash ratio of $15 \%$ and Guney et al. (2003) observe that the average cash ratio of the company is $14 \%$. Therefore, a question rises, why firms hold cash? For ascertaining the answer several studies have been undertaken. In these studies, generally two contradictory theories exist: Trade-off theory (Myers, 1977) and the Pecking order model (Myers \& Majluf, 1984). In the trade-off theory an optimal cash balance should be maintained, which results from weighting its marginal benefits and costs. On the other hand, pecking order theory, which is the extension work of trade off theory, does not believe the idea of optimal cash level. It is utilized as buffer between retained earnings and investment needs.

Earlier studies like Opler et al. (1999) and Kim et al. (1998) supported the tradeoff theory. Cash level not only increases the growth opportunities of the company but also increases the business risk and capital expenditure. And it is difficult to operate in the capital market. On the other hand it decreases with its size, leverage and its dividend payments. Most of the studies supported the trade-off theory and show that firms which have superior investor protection and in countries where capital markets are better developed hold less cash. Dittmar (2002), Ferreira and Vilela (2004) and Guney et al. (2003) are the supporters of this type theory.

Saddour (2006) made a study on French Firm regarding Holding of Cash. In his study he characterizes the French market as high levels of trade credit. He shows that French firms holds cash on an average $13 \%$ of their total assets. For that he presents two capital structure theories viz. trade off theory and pecking order theory. He then tries to show which of these two theories would better explain the cash holdings. 
For this type of analysis he sub divides the sample into two sub samples, growth companies and mature firms in his study he collected a sample of 297 French companies over a period of five years i.e. 19982002. In this study he examines whether or not cash holdings was positively associated with its market value. In this study he attempts to prove that both trade off theory and pecking order theories play an important role in explaining the needs of cash holdings. He also reports that growth firm holds more cash than mature firms and states growth firms and mature firms have various needs for holding cash. He shows that cash holding is negatively associated with the firm's characteristics, size, level of liquid assets and short-term debt. In case of mature firm the holding of cash depends on the form of dividends or stock repurchased and decreases with their research and development expenses. But such result does not confirm with the result previous studies. Ultimately he reports that cash level of mature companies increases with their investment level and cash level of mature companies is negatively related with trade credit. It confirms the findings of Kim et al. (1998) and Deloof and Jegers's (1999) studies.

\section{Review of Literatures}

Deloof and Jegers (1999) undertook a study on working capital management. His study was based on cash conversion cycle. He uses various measures relating to the time lag between expenditure for the purchase of raw materials and collection of sales of finished goods. He argues that the longer the time lag is, the larger the investment in working capital is.

Farris et al. (2011) made a study on cash to cash metric. For this they initially taken 21608 firms but latter such firms were reduced to 5884. This study presented an overview of cash to cash and its calculation, comparisons between product and service industries etc. The study also disclosed that cashto-cash knowledge of managers helped the service industries improve their liquidity position and overall value.

San-Jose et al. (2008) conducted a study on approximately 501 Spanish firms with more than 10 employees using confirmatory factor analysis. In this study, it was observed that the P-value of the chisquare does not attain the recommended figure because of the size of the sample. They state that cash management was a culture that forms part of the strategy of companies and dependent more on managers themselves than the characteristics of companies.

Padachi (2006) worked on Trends in working capital management and its impact on firm's performance. For this study he selected 58 small manufacturing firms in Mauritius over the period 1998 -2003. He reports that high investment in inventories and receivables was associated with lower profitability. For this he used return on total assets as a measure of profitability. The findings of the study revealed an increasing trend in the short-term component of working capital financing.

Kim et al. (1998) made a study on corporate liquidity in 1998. They used the logarithmic growth rate in the index of leading economic indicators as a proxy for the extent of profitable investment opportunities. They found that a firm's cash holdings increase with the level of investment opportunities and uncertainty in future cash flows. Similar type of study was conducted by Opler et al. (1999). They also found the same results.

Baskin and Maritani (1999) in their study of Corporate Liquidity in Games of Monopoly Power argued that firms with abundant investment opportunities also had an incentive to hold more cash to maintain their competitive positions. He also showed that holding excess cash might deter competition in a firm's product markets. 


\section{Objectives of the Study}

(i) To measure the cash conversion cycle of the selected firms from five various sectors with the help of receivables conversion period (RCP), inventory conversion period (ICP) and payment of deferral period (PDP).

(ii) To measure the degree of relationship between the cash conversion cycle and inventory turnover ratio (ITR), current ratio (CR), debtors turnover ratio (DTR), debtors more than six months and creditors turnover ratio (CTR) in each of the companies under study by using Pearson's simple correlation technique and to test such coefficients.

(iii) To analyze the joint impact of earning capability (RONW), size of the organization and cumulative profitability (Shareholders' Fund) on the cash conversion cycle of the companies with the help of appropriate statistical measure (i.e. multiple regression analysis) and to test the significance of such regression coefficients.

(iv) To measure the average cash holding of the selected companies from five different sectors from cash balance at the opening and at the end.

(v) To measure the degree of relationship between the cash holding and degree of financial leverage, size of the organization, investment and profitability in each of the selected companies under study by using Pearson's simple correlation technique and to test such coefficients.

(vi) To analyze the joint influence of DFL, Size of the organization and Investment on cash holding of the companies with the help of appropriate statistical measures like multiple regression analysis and to test the significance of such regression coefficients.

(vii) Finally, to examine whether the CCC influence the Average Cash Holding or not?

\section{Methodology of the study}

For measuring the CCC here we considered FMCG Sector. The data of the selected companies for the period 2002 to 2011 used in this study have been taken from the secondary sources i.e. Capitaline Corporate Database of Capital Market Publishers (I) Ltd. Mumbai. For the purpose of our study different companies of FMCG sector are selected following the purposive sampling procedure. Receivable conversion period, inventory conversion period and payment of deferral period are used to measure the cash conversion cycle. Shorter cash conversion cycle means better liquidity position of the organization. Here, we established the relationship between CCC and debtors more than six months, CCC and CR, CCC and inventory turnover ratio, CCC and debtors turnover ratio and CCC and creditors turnover ratio. Debtors more than six months mean debtors from whom money is collected after six months. It is riskier to the organization and also blocks cash for long period and reduces the liquidity position. Liquidity of the organization has been represented by the current ratio which is obtained by dividing the current assets to current liabilities. Efficiency of the inventory management has been measured by inventory turnover ratio (ITR) which is the ratio between cost of goods sold and average stock. Debtors' turnover ratio (DTR) is the ratio of credit sales to average receivables. Organization's ability to avail credit facility from suppliers has been measured by creditors' turnover ratio (CTR) which is the ratio of credit purchase to average payables.

Profitability, size of the organization and cumulative profitability can influence the cash conversion cycle of the organization. In this study, profitability has been measured by return on net worth (RONW), size of the organization has been represented through the amount equal to the log value of total assets. Shareholders fund has been selected in this study as cumulative profitability which consists of equity share capital and reserve surpluses. The log value of shareholders' fund represents the cumulative profitability. We used the log value for getting the continuously compounded relation or growth of companies' assets and shareholders' fund. For analyzing the data statistical tools like arithmetic mean, standard deviation coefficient of variation etc. and statistical techniques like Pearson's simple 
correlation analysis and multiple regression analysis and statistical test like ' $\mathrm{t}$ ' test have been applied at appropriate places.

In this study we examined the relationship between average cash holding and DFL, average cash holding and Investment and average cash holding and profitability (RONW). Degree of financial leverage (DFL) is computed with the help of the following formula, DFL = Operating Profit (EBIT) / (Operating Profit - Interest)

Financial leverage arises due to use of fixed charges bearing capital in the capital structure like debt capital.

Higher debt capital means higher financial leverage. DFL measures the financial risk of the business. DFL affects the cash holding of the organization. More external borrowing means more cash holding. It can also be said that external borrowing replaces cash holding. Size of the organization has been represented through the amount equal to the log value of total assets. Size of the organization can affect the corporate cash holding. Generally, small firms hold more cash not only for higher costs of use of external funds but also for borrowing constraints. But, large organization means too many expenses and for that purpose we need large cash holding. Investment of the organization has been represented through the figure equal to the log value of total amount of Investment. Organizations which have numerous investment opportunities but uncertain internal cash flow hold more cash otherwise borrowing external funds for profitable investment opportunity is costly. In this study profitability has been measured by the return on net worth (RONW). General principle is that the higher the liquidity the lowers the profitability. Holding more cash increases the short-term debt paying capacity of the organization, but decreases the profitability by not using the excess or unused fund in some other profitable projects. For analyzing the data statistical tools like arithmetic mean, standard deviation, coefficient of variation etc. and statistical techniques like Pearson's simple correlation analysis and multiple regression analysis and statistical test like ' $t$ ' test have been applied in appropriate places.

\section{Findings of the Study}

Table 1 shows that the CCC of Britannia Industries Ltd. (Britannia) is highest in the year 2008 (30.62 days) and lowest in the year 2002 (11.56 days). On an average it is 21.1 days. During the first half of the study period it registered an upward rising trend whereas during the second half of the study period a mixed trend has been noticed. The liquidity position of the company is quite good during the study period.

\section{Table 1}

Analysis of Cash Conversion Cycle of Selected Companies of FMCG Sector (in Days)

\begin{tabular}{cccccccccccc}
\hline COMPANIES & 2002 & 2003 & 2004 & 2005 & 2006 & 2007 & 2008 & 2009 & 2010 & 2011 & AVG \\
\hline BRITANIA & 11.56 & 12.24 & 18.77 & 23.41 & 23.86 & 22.38 & 30.62 & 28.09 & 21.33 & 18.33 & 21.1 \\
DABUR & 73.97 & 70.36 & 52.45 & 24.61 & 20.16 & 20.09 & 25.39 & 33.66 & 34.23 & 43.75 & 39.9 \\
HUL & -13.7 & -13.87 & -12.35 & -5.70 & -16.21 & -21.64 & -24.95 & -12.24 & -29.20 & -31.97 & -18.2 \\
MARICO & 25.89 & 26.20 & 23.78 & 25.90 & 21.96 & -0.57 & 4.46 & 24.63 & 43.15 & 56.34 & 25.2 \\
NESTLE & 35.68 & 33.82 & 30.35 & 26.85 & 24.59 & 25.14 & 27.38 & 27.26 & 25.87 & 23.26 & 28 \\
\hline
\end{tabular}

Source: Compiled and computed from ‘Capitaline Corporate Database’ of Capital Market Publishers (I) Ltd., Mumbai

In case of Dabur India Ltd. (Dabur), the CCC is highest in 2002 (73.97days) and smallest in 2007 (20.16 days). On an average it is 39.9 days. During the first half of the study period it decreases significantly but during the second half of the study period it increases gradually. So from liquidity point of view middle years are best where CCC is below average. Hence the liquidity position of the company is sound enough. 
If we see the CCC of Hindustan Unilever Ltd. (HUL), it portrays a different picture from other companies selected in this study. All the CCCs are negative here. It is exceptional among all companies regarding CCC. Probably it is due to large deferral period for payment. Table 1 shows that it is highest in the year 2005(-5.7days) and smallest in the last year of the study period i.e. in the year 2011(-31.97 days). On an average it is (-) 18.2 days. Due to large deferral periods it signified an extra ordinary liquidity position of the company. Table 1 also depicts that in case of Marico Industries Ltd. (Marico) the CCC is highest in the year 2011(56.34 days) and minimum in the year 2007(-0.57 days). On an average it is 25.2 days. A mixed trend of CCC is noticed in the study period. The company registered a steady liquidity position during the study period. From Table 1 it has been found that the CCC of Nestle India Ltd. (Nestle) is maximum in the year 2002(35.68days) and minimum in the year 2011 (23.26days). On an average it is 28 days. During the first half of the study period it decreases steadily but a mixed trend is noticed in the second half of the study period. So the liquidity position of the company is quite good considering the CCC. Among five FMCG companies, HUL is exceptional. Though, all the companies registered steady liquidity position. It proves that in all the companies the liquidity management is efficient. From Table 2, companies selected in this study, HUL occupied the first position in respect of average CCC and it followed by Britannia, Marico, Nestle and Dabur respectively. In respect of consistency of constructing CCC, HUL ranked as first and it followed by Nestle, Britannia, Dabur and Marico respectively. Considering both average and consistency HUL captured the top most position and Britannia is in second position, followed by Nestle, Marico and Dabur respectively in that order.

\section{Table 2}

Ranking on the basis of Average and Consistency of Cash conversion Cycle Of the Selected Companies from FMCG Sector

\begin{tabular}{cccccccc}
\hline COMPANIES & AVG. & SD & $\begin{array}{c}\text { RANK OF } \\
\text { AVG. }\end{array}$ & $\begin{array}{c}\text { COEFFICIENT } \\
\text { OF } \\
\text { VARIATION }\end{array}$ & $\begin{array}{c}\text { RANK } \\
\text { OF } \\
\text { COEFFICIENT }\end{array}$ & $\begin{array}{c}\text { TOTAL } \\
\text { RANK }\end{array}$ & $\begin{array}{c}\text { OVER ALL } \\
\text { RANK }\end{array}$ \\
\hline BRITANIA & 21.1 & 6.11675 & 2 & 29.046 & 3 & 5 & 2 \\
DABUR & 39.9 & 19.8841 & 5 & 49.876 & 4 & 9 & 5 \\
HUL & -18.2 & 8.41268 & 1 & -46.267 & 1 & 2 & 1 \\
MARICO & 25.2 & 16.3331 & 3 & 64.881 & 5 & 2 & 4 \\
NESTLE & 28 & 4.0475 & 4 & 14.445 & 2 & 6 & 3 \\
\hline
\end{tabular}

Coefficient of Correlation is the measurement of degree of association between two variables. A positive value of ' $r$ ' indicated high values of one variable are generally associated with the high values of other variables and low values with low values. In Table 4 an effort has been made to measure the degree of relationship between Cash Conversion Cycle (CCC) and each of the factors related with CCC such as inventory turnover ratio (ITR), current ratio (CR), debtors turnover ratio (DTR), debtors more than six months (Debt $>6$ Months) and creditors turnover ratio(CTR). To test the significance of such coefficient, ' $\mathrm{t}$ ' test has been applied.

Table 3

Karl Pearson's simple correlation analysis between CCC and ITR, CR, DTR, Debt > 6 months and CTR of the selected companies from FMCG sector

\begin{tabular}{|c|c|c|c|c|c|c|c|c|c|c|}
\hline \multirow[t]{2}{*}{ Firms } & \multicolumn{2}{|c|}{ CCC \& ITR } & \multicolumn{2}{|c|}{ CCC \& CR } & \multicolumn{2}{|c|}{ CCC \& DTR } & \multicolumn{2}{|c|}{$\begin{array}{c}\text { CCC \& DEBT }>6 \\
\text { MONTHS }\end{array}$} & \multicolumn{2}{|c|}{ CCC \& CTR } \\
\hline & (r) & $\begin{array}{c}\mathrm{t} \text { ' } \\
\text { Value }\end{array}$ & (r) & $\begin{array}{c}\mathrm{t} \text { ' } \\
\text { Value }\end{array}$ & (r) & $\begin{array}{c}\text { 't' } \\
\text { Value }\end{array}$ & (r) & $\begin{array}{c}\text { 't' } \\
\text { Value }\end{array}$ & (r) & $\begin{array}{c}\text { 't' } \\
\text { Value }\end{array}$ \\
\hline BRITANNIA & $0.979 * *$ & 13.58 & $-0.696^{*}$ & -2.74 & -0.390 & -1.2 & -0.458 & -1.46 & -0.525 & -1.745 \\
\hline DABUR & $0.938 * *$ & 7.654 & $-0.805^{* *}$ & -3.84 & $0.984 * *$ & 15.62 & -0.2 & -0.58 & $-0.747^{*}$ & -3.178 \\
\hline HUL & 0.313 & 0.932 & -0.342 & -1.03 & 0.322 & 0.962 & 0.072 & 0.204 & -0.309 & -0.919 \\
\hline MARICO & -0.168 & -0.48 & 0.445 & 1.405 & -0.091 & -0.26 & 0.156 & 0.447 & 0.510 & 1.677 \\
\hline NESTLE & $0.986 * *$ & 16.73 & $-0.914 * *$ & -6.37 & 0.576 & 1.993 & 0.215 & 0.623 & $-0.767 * *$ & -3.381 \\
\hline
\end{tabular}


It has been depicted from Table 3 that in case of FMCG sector the correlation coefficient between CCC and ITR in Britannia, Dabur, HUL and Nestle are 0.979, 0.938, 0.313 and 0.986 respectively. It implies that the strength of positive association between CCC and ITR in Britannia, Dabur, and Nestle are highly significant. The correlation coefficient between CCC and ITR in Marico is negative. It implies that the ITR is negatively influenced the CCC in case of Britannia, Dabur and Nestle. In FMCG sector Table 3 shows that the correlation coefficient between CCC and CR in Britannia, Dabur, HUL and Nestle are (-) 0.696, (-) 0.805, (-) 0.342 and (-) 0.914 respectively. Out of which the correlation coefficient between CCC and CR in Britannia, Dabur and Nestle is statistically significant at 5\% level of significance. It indicates negative association between CCC and CR which is not expected. Only in case of Marico Ltd. low positive correlation between CCC and CR is viewed which is 0.445 .

In FMCG sector, Table 3 exhibits that the correlation coefficients between CCC and DTR in Dabur, HUL and Nestle are $0.984,0.322$ and 0.576 respectively. Out of which the correlation coefficients between CCC and DTR of Dabur is statistically significant both at 5\% and 1\% level of significance. On the other hand, Britannia and Marico registered a negative correlation between CCC and DTR which are (-) 0.390 and (-) 0.091 respectively. It indicates sound debtors management which helped the companies to minimize its CCC. In FMCG sector, Table 3 depicts that correlation coefficient between CCC and debtors more than six months in Britannia and Dabur are (-) 0.458 and (-) 0.2 respectively. It indicates the negative association between them which is desirable in the organization. But, the correlation coefficient between CCC and debtors more than six months in HUL, Marico and Nestle are 0.072, 0.156 and 0.215 respectively. It indicates very low positive relationship between CCC and debtors more than six months which is also not desirable. It is due to inefficient debt collection policy which increases the CCC. From Table 3 it is found that in case of FMCG sector the correlation coefficient of all the companies selected under study except Marico establishes high negative relationship. The correlation coefficient between CCC and CTR in Britannia, Dabur, HUL and Nestle are (-) 0.525, (-) 0.747, (-) 0.309 and (-) 0.767 respectively. Out of which the same in case of Dabur and Nestle is statistically significant at 5\% level. It implies negative relationship between CCC and CTR. It is not desirable. It portrays the sound creditors' management of the companies in minimization of CCC. The correlation coefficient of CCC and CTR in Marico is 0.510. It establishes positive relationship between CCC and CTR. It portrays the sound creditors' management of the companies in minimization of CCC.

\section{Table 4}

Analysis of Multiple Regression of CCC on RONW, Size of Org. and shareholders' Fund of the Selected Companies of FMCG Sector. Regression Equation is CCC $=\mathrm{a}_{0}+\mathrm{a}_{1} \mathrm{RONW}+\mathrm{a}_{2} \mathrm{Size}$ of Org. $+\mathrm{a}_{3}$ Shareholders' Fund

\begin{tabular}{|c|c|c|c|c|c|}
\hline \multirow[t]{2}{*}{ COMPANY } & \multicolumn{3}{|c|}{ PARTIAL REGRESSION COEFFICIENT } & \multirow[b]{2}{*}{ CONSTANT } & \multirow[t]{2}{*}{$\mathrm{R}^{2} \mathrm{ED}$} \\
\hline & RONW & $\begin{array}{c}\text { SIZE OF THE } \\
\text { ORGANISATION }\end{array}$ & $\begin{array}{c}\text { SHAREHOLDERS' } \\
\text { FUND }\end{array}$ & & \\
\hline BRITANNIA & $\begin{array}{c}-0.131 \\
(-0.260)\end{array}$ & $\begin{array}{c}0.581 \\
(0.030)\end{array}$ & $\begin{array}{c}-40.371 \\
(-2.358)^{* *}\end{array}$ & $\begin{array}{l}129.600 \\
(2.633)\end{array}$ & 0.555 \\
\hline DABUR & $\begin{array}{c}0.195 \\
(1.432)\end{array}$ & $\begin{array}{l}-28.017 \\
(-0.685)\end{array}$ & $\begin{array}{l}18.039 \\
(0.382)\end{array}$ & $\begin{array}{l}31.072 \\
(1.784)\end{array}$ & 0.747 \\
\hline HUL & $\begin{array}{c}0.113 \\
(0.491)\end{array}$ & $\begin{array}{c}-116.547 \\
(-2.449)^{* *}\end{array}$ & $\begin{array}{l}-101.314 \\
(2.183)^{*}\end{array}$ & $\begin{array}{l}25.137 \\
(0.157)\end{array}$ & 0.598 \\
\hline MARICO & $\begin{array}{c}-0.039 \\
(-0.272)\end{array}$ & $\begin{array}{c}29.968 \\
(2.009)^{*}\end{array}$ & $\begin{array}{c}-46.880 \\
(-2.704)^{* *}\end{array}$ & $\begin{array}{l}48.774 \\
(5.161)\end{array}$ & 0.444 \\
\hline NESTLE & $\begin{array}{c}-0.031 \\
(-0.853)\end{array}$ & $\begin{array}{l}-17.819 \\
(-2.201)^{*}\end{array}$ & $\begin{array}{c}25.876 \\
(2.848)^{*}\end{array}$ & $\begin{array}{c}-4.219 \\
(-0.447)\end{array}$ & 0.755 \\
\hline
\end{tabular}

In Table 4 an attempt has been made to assess the influence profitability, size of the organization and cumulative profitability on Cash Conversion Cycle. In this study, return on net-worth (RONW) has been taken as the measure of owners' profitability, log value of total assets has been taken as the measure of size of the organization and shareholder's fund has been taken as the measure of cumulative 
profitability. The linear regression equation has been fitted in this study is CCC $=\mathrm{b}_{0}+\mathrm{b}_{1} \mathrm{RONW}+\mathrm{b}_{2}$ Size of Org. $+\mathrm{b}_{3}$ Shareholders' fund, where $\mathrm{b}_{0}$ is the value of intercept term (constant ) and $\mathrm{b}_{1}, \mathrm{~b}_{2}$ and $b_{3}$ are the slopes of the line i.e. the regression coefficient of CCC on RONW, size of org. and Shareholders' fund. This regression equation has been tested by ' $t$ ' test. Under FMCG companies Table 4 shows that for one unit increase in RONW, the CCC of Britannia go down by 0.131 units which is statistically insignificant at $5 \%$ level. The Table 5 also shows that for one unit increase in size of the organization the CCC of Britannia is stepped up by 0.581 units only, which is also statistically insignificant. On the other hand Table 4 shows that for one unit increase in cumulative profitability the CCC of Britannia go down by 40.371 units which is statistically significant at $5 \%$ level. It indicates that RONW and cumulative profitability negatively influenced the CCC of the company. It also indicates that only size of the organization influenced the CCC of the company positively. The coefficient of determination $\left(\mathrm{R}^{2}\right)$ makes it clear that $55.5 \%$ of the variation of the company's CCC is accounted for by the variation in RONW, Size of Org and Shareholders' fund.

\section{Table 5}

Analysis of Average Cash Holding (Avg. cash holding as percentage of total assets) of Selected Companies of FMCG sector Rs. in crore (also in \% of total assets

\begin{tabular}{|c|c|c|c|c|c|c|c|c|c|c|c|}
\hline \multirow[t]{2}{*}{ Firms } & \multicolumn{10}{|c|}{ Years } & \multirow[t]{2}{*}{$\mathrm{AVG}$} \\
\hline & 2002 & 2003 & 2004 & 2005 & 2006 & 2007 & 2008 & 2009 & 2010 & 2011 & \\
\hline BRITANI & 46.33 & 65.45 & 41.81 & 109.8 & 146.27 & 190.42 & 231.86 & 281.45 & 308.87 & 9.84 & 143 \\
\hline DABUR & 22.61 & 29.68 & 16.42 & 11.27 & 24.35 & 47.35 & 61.15 & 105.97 & 157.88 & 178.16 & 65.5 \\
\hline HUL & 719.16 & 927.9 & 874.56 & 752.3 & 526.54 & 390.87 & 308.9 & 989.11 & 1834.8 & 1766.1 & 909 \\
\hline MARICO & 7.09 & 14.26 & 20.98 & 20.74 & 22.95 & 26.44 & 27.37 & 26.46 & 17.10 & 14.69 & 19.8 \\
\hline NESTLE & 12.39 & 26.58 & 59.21 & 122.1 & 152.69 & 147.6 & 143.15 & 180.37 & 293.72 & 382.41 & 152 \\
\hline
\end{tabular}

Source: Compiled and computed from ‘Capitaline Corporate Database’ of Capital Market Publishers (I) Ltd., Mumbai

It is found from Table 4 that for one unit increase in CONW the CCC of Dabur increased by 0.195 units which is not statistically significant at $5 \%$ level. The table also depicts that for one unit increase in size of the organization the CCC of Dabur is highly decreased by 28.017 units which is also not significant. On the other hand the table shows that for one unit increase in cumulative profitability the CCC of the company is highly increase by 18.039 units. It implies that both profitability and cumulative profitability influenced the company positively while size of the organization influenced the CCC of the company negatively. The coefficient of determination $\left(\mathrm{R}^{2}\right)$ makes it clear that $74.7 \%$ of the variation of the company's CCC is accounted for by the variation in RONW, Size of Org and Shareholders' fund.

It has been found from Table 4 that for one unit increase in RONW the CCC of HUL increased by only 0.113 unit which is not statistically significant. But the Table 4 shows that due to one unit increase in size of the organization and cumulative profitability the CCC of HUL decreased by 116.547 units and 101.314 units respectively out of which earlier one is statistically significant at $5 \%$ level and the later one is statistically significant at $10 \%$ level. It may be due to negative CCC.

It indicates that size of the company and cumulative profitability negatively influenced the company, whereas the influence of RONW on CCC of the company is positive. The coefficient of determination $\left(\mathrm{R}^{2}\right)$ makes it clear that $59.8 \%$ of the variation of the company's CCC is accounted for by the variation in RONW, Size of the Org. and Shareholders' fund.

Table- 4 shows that for one unit increase in RONW the CCC of Marico go down by 0.039 units, which is statistically insignificant at $5 \%$ level. The table also shows that for one unit increase in size of the organization the CCC of Marico stepped up by 29.968 units which is statistically significant at $10 \%$ level. On the other hand, for one unit increase in cumulative profitability the CCC of Marico heavily goes down by 46.880 units which is also statistically significant at $5 \%$ level. It implies that profitability and cumulative profitability negatively influenced the CCC of Marico Ltd. while size of the 
organization influenced the CCC positively during the study period. The coefficient of determination $\left(\mathrm{R}^{2}\right)$ makes it clear that $44.4 \%$ of the variation of the company's CCC is accounted for by the variation in RONW, Size of Org and Shareholders’ fund.

It is found from Table 4 that for one unit increase in RONW and size of the organization the CCC of Nestle stepped down by 0.031 and 17.819 units respectively and the later one is statistically insignificant at $10 \%$ level. On the other hand table- 4 shows that for one unit increase in cumulative profitability the CCC of Nestle go up by 25.876 units which is statistically significant at $5 \%$ level. It implies that RONW and size of the organization negatively influenced the CCC of the company whereas the influence of cumulative profitability on CCC is positive. The coefficient of determination $\left(\mathrm{R}^{2}\right)$ makes it clear that $75.5 \%$ of the variation of the company's CCC is accounted for by the variation in RONW, Size of the Org. and Shareholders' fund. Therefore, from table- 4 we can say that in case of HUL in the FMCG sector the negative influence of size of the organization and cumulative profitability is very much noticeable than the other companies selected in this study.

It is found from Table 5 that in case of Britannia Industries Ltd. (Britannia) the Average Cash Holding(ACH) is highest in the year 2010 (Rs.308.87Crore) and lowest in the year 2011 (Rs.9.84Crore). On an average it is Rs. 143 Crore. The ACH of the company fluctuated throughout the study period. In the last year of our study period the cash level of the company decreased drastically. In the year 2010 the average cash holding as percentage of total assets is highest which is 37.39\%. Large investment or refund of external funds may be the reason foe drastic fall in cash balance of the company. The liquidity position of the company in respect of $\mathrm{ACH}$ is sound enough throughout the study period except in the year 2011.

Table 5 reveals that the ACH of Dabur India Ltd. (Dabur) is highest in the year 2011 (Rs.178.16 Crore) and lowest in the year 2005 (Rs.11.27 Crore). On an average it is Rs. 65.5 Crore. The average cash holding as percentage of total assets is highest in the year2010 (18.37\%). During the first half of the study period the ACH of the company is fluctuated whereas in the second half of the study period a steady increase in ACH is noticed. Therefore, the company has improved its liquidity position in the last phase of the study period.

From Table 5 it is found that the ACH of Hindustan Unilever Ltd. (HUL) is highest in the year 2010 (Rs.1834.8 Crore) and lowest in the year 2008(Rs.308.9 Crore). On an average it is Rs.909 Crore. From the point of view of average cash holding as percentage of total assets is highest in the year 2010 (71.01\%).Throughout the study period the company maintained a fluctuating trend in ACH. Though, the liquidity condition of the company in respect of ACH is good.

It has been observed from Table 5 that the ACH of Marico Industries Ltd. (Marico) is highest in the year 2008 (Rs.27.365 Crore) and lowest in the year 2002(Rs.7.085 Crore). On an average it is Rs.19.8Crore. First few years of the study period the ACH of the company increases but after that it fluctuated. The average cash holding as percentage of total assets is highest in the year 2004 which is $11.08 \%$. Throughout the study period, the company holds low level of cash. From the point of view of ACH the company maintained low level of liquidity during the study period.

It is found from Table 5 that the ACH of Nestle India Ltd. (Nestle) is highest in the year 2011 (Rs.382.405 Crore) and lowest in the year 2002(Rs.12.385 Crore). On an average it is Rs.152Crore. An increasing trend in ACH of the company is noticed during the first half of the study period whereas the $\mathrm{ACH}$ of the company has fluctuated in the second half of the study period. Similarly, the average cash holding as percentage of total assets is highest in the year 2010 which is $50.53 \%$. The company improved its cash level, in last phase of the study period which helped the company to improve its liquidity condition. 
Therefore in FMCG sector the average cash holding of HUL is best. It signifies its greater liquidity. On the other hand Marico registered poorer liquidity for it lower cash holding. It is found from Table 6 that among FMCG sector the Average Cash Holding as \% of Total Assets, HUL is the highest, followed by Nestle, Britannia, Dabur and Marico respectively in that order. The table also depicts that in respect of consistency in constructing ACH, Marico occupied the top position followed by HUL, Britannia, Nestle, and Dabur respectively in that order. Combining both average and consistency aspect together HUL holds the first position and it followed by Britannia, Marico, Nestle and Dabur in that order respectively. Coefficient of correlation is the measurement of degree of association between two variables. A positive value of ' $r$ ' indicated high values of one variable are generally associated with the high values of other variables and low values with low values. In Table 7 an effort has been made to measure the degree of relationship between $\mathrm{ACH}$ and each of the factors related with cash holding such as degree of financial risk (DFL), size of the organization, Investment of the organization and lastly profitability (RONW). To test the significance of such coefficient ' $t$ ' test has been applied.

\section{Table 6}

Ranking on the basis of Average and Consistency of Average Cash Holding Of the Selected Companies from FMCG Sector

\begin{tabular}{clcccccc}
\hline Companies & $\begin{array}{c}\text { Avg. Cash as \% } \\
\text { of Total Assets }\end{array}$ & SD & $\begin{array}{c}\text { Rank of } \\
\text { Avg. }\end{array}$ & $\begin{array}{c}\text { Coefficients of } \\
\text { variation }\end{array}$ & $\begin{array}{c}\text { Rank of } \\
\text { Coefficients }\end{array}$ & $\begin{array}{c}\text { Total } \\
\text { Rank }\end{array}$ & $\begin{array}{c}\text { Over all } \\
\text { Rank }\end{array}$ \\
\hline BRITANIA & 20.9 & 100.6 & 3 & 70.27 & 3 & 6 & 2 \\
DABUR & 8.87 & 57.77 & 4 & 88.23 & 5 & 9 & 5 \\
HUL & 32.6 & 493.5 & 1 & 54.29 & 2 & 3 & 1 \\
MARICO & 5.26 & 6.194 & 5 & 31.27 & 1 & 6 & 2 \\
NESTLE & 31.1 & 109 & 2 & 71.7 & 4 & 6 & 2 \\
\hline
\end{tabular}

Source: Compiled and computed from ‘Capitaline Corporate Database’ of Capital Market Publishers (I) Ltd., Mumbai.

It is found from Table 7 that in FMCG sector the correlation coefficient between ACH and DFL in Britannia, Dabur, HUL and Nestle are (-) 0.638, (-) 0.346, (-) 0.106 and (-) 0.899 respectively. All the correlation coefficients are negative and out of which coefficient of Britannia are statistically significant at $5 \%$ level and coefficient of Nestle Ltd is significant both at 5\% and $1 \%$ level of significance.

\section{Table 7}

Karl Pearson's Simple Correlation Analysis between AVG Cash Holding and DFL, Size of Org., Investment and RONW of the Selected Companies from FMCG Sector

\begin{tabular}{|c|c|c|c|c|c|c|c|c|}
\hline \multirow[t]{2}{*}{ Firms } & \multicolumn{2}{|c|}{$\begin{array}{c}\text { AVG CASH } \\
\text { HOLDING \& } \\
\text { DFL }\end{array}$} & \multicolumn{2}{|c|}{$\begin{array}{c}\text { AVG CASH } \\
\text { HOLDING \& } \\
\text { SIZE OF ORG. }\end{array}$} & \multicolumn{2}{|c|}{$\begin{array}{c}\text { AVG CASH HOLDING } \\
\& \\
\text { INVESTMENT }\end{array}$} & \multicolumn{2}{|c|}{$\begin{array}{c}\text { AVG CASH } \\
\text { HOLDING \& } \\
\text { RONW }\end{array}$} \\
\hline & (r) & 't' Value & (r) & 't' Value & (r) & 't' Value & (r) & 't' Value \\
\hline BRITANNIA & $-0.638^{*}$ & -2.3 & 0.167 & 0.4791 & -0.046 & -0.13 & -0.441 & -1.39 \\
\hline DABUR & -0.346 & -1 & $0.867 * *$ & 4.9211 & $0.648 *$ & 2.406 & 0.547 & 1.848 \\
\hline HUL & -0.106 & -0.3 & 0.388 & 1.1907 & -0.298 & -0.883 & 0.383 & 1.173 \\
\hline MARICO & 0.362 & 1.1 & 0.261 & 0.7647 & 0.611 & 2.183 & 0.749* & 3.197 \\
\hline NESTLE & $-0.899 * *$ & -5.8 & 0.592 & 2.0776 & $0.834^{* *}$ & 4.275 & $0.826 * *$ & 4.145 \\
\hline
\end{tabular}

It implies that the negative association between ACH and DFL in Britannia, Dabur, HUL and Nestle are highly impressive. Only in case of Marico the correlation coefficient between ACH and DFL is positive. It implies positive relationship between ACH and DFL in Marico.

Now, from Table 7 it is observed that the correlation coefficient between ACH and Size of the organization in all the companies selected in this study from FMCG sector are positive. Such correlation coefficient between ACH and Size of the organization in Britannia, Dabur, HUL, Marico and Nestle 
are $0.167,0.867,0.388,0.261$ and 0.592 respectively. In that the coefficient in Dabur is statistically significant both at 5\% and 1\% level. IT implies that all the FMCG companies selected in this study have positive relationship between $\mathrm{ACH}$ and Size of the organization.

In FMCG sector, Table 7 shows that the correlation coefficient between ACH and Investment in Britannia, Dabur, HUL, Marico and Nestle are (-) 0.046, 0.648, (-) 0.298, 0.611 and 0.834 respectively. In these correlation coefficients, the same in Dabur and Nestle are statistically significant at $5 \%$ and both at 5\% and 1\% level of significance respectively. It signifies that in Dabur, Marico and Nestle the relationship between ACH and Investment is positive. But the correlation coefficient between ACH and Investment in Britannia and HUL is negative. It portrays that in Britannia and HUL, ACH is negatively associated with Investment.

It is found from Table 7 that in FMCG sector the correlation coefficient between ACH and RONW in Britannia, Dabur, HUL, Marico and Nestle Ltd. are (-) 0.441, 0.547, 0.383, 0.749 and 0.826 respectively. Out of which the correlation coefficient between ACH and RONW in Dabur, HUL, Marico and Nestle are positive and coefficient of last two companies is statistically significant at 5\% and both at 5\% and 1\% level of significance respectively. It signifies that in Dabur, HUL, Marico and Nestle the relationship between ACH and RONW is positive and significant. On the other hand the correlation coefficient between ACH and RONW in Britannia is negative. It indicates that in Britannia ACH is negatively related with RONW.

\section{Table 8}

Analysis of Multiple Regression of Avg. Cash Holding on DFL, Size of Org. and Investment of the Selected Companies of FMCG Sector.

Regression Equation is Avg. Cash Holding $=\mathrm{a}_{0}+\mathrm{a}_{1} \mathrm{DFL}+\mathrm{a}_{2}$ Size of Org. $+\mathrm{a}_{3}$ Investment

\begin{tabular}{|c|c|c|c|c|c|}
\hline \multirow{2}{*}{ Firm } & \multicolumn{3}{|c|}{ PARTIAL REGRESSION COEFFICIENT } & \multirow{2}{*}{ CONSTANT } & \multirow{2}{*}{$\mathrm{R}_{\mathrm{ED}}^{2}$} \\
\hline & DFL & $\begin{array}{c}\text { SIZE OF THE } \\
\text { ORGANISTION }\end{array}$ & INVESTMENT & & \\
\hline BRITANNIA & $\begin{array}{c}-11.814 \\
(-4.329)^{* * *}\end{array}$ & $\begin{array}{c}3.104 \\
(2.231)^{*}\end{array}$ & $\begin{array}{c}-0.093 \\
(-0.051)\end{array}$ & $\begin{array}{c}5.995 \\
(2.324)\end{array}$ & 0.792 \\
\hline DABUR & $\begin{array}{c}-3.589 \\
(-3.293)^{* *}\end{array}$ & $\begin{array}{c}2.761 \\
(5.819)^{* * *}\end{array}$ & $\begin{array}{c}-1.287 \\
(-2.342)^{* *}\end{array}$ & $\begin{array}{c}0.903 \\
(0.588)\end{array}$ & 0.915 \\
\hline HUL & $\begin{array}{c}-2.191 \\
(-0.636)\end{array}$ & $\begin{array}{c}1.406 \\
(1.894)^{*}\end{array}$ & $\begin{array}{c}-0.478 \\
(-1.477)\end{array}$ & $\begin{array}{c}1.803 \\
(0.527)\end{array}$ & 0.430 \\
\hline MARICO & $\begin{array}{c}1.342 \\
(1.202)\end{array}$ & $\begin{array}{c}-0.584 \\
(-2.215)^{*}\end{array}$ & $\begin{array}{c}0.314 \\
(3.075)^{* *}\end{array}$ & $\begin{array}{c}0.856 \\
(0.748)\end{array}$ & 0.668 \\
\hline NESTLE & $\begin{array}{l}-32.854 \\
(-5.449)^{* * *}\end{array}$ & $\begin{array}{c}1.455 \\
(5.314)^{* * *}\end{array}$ & $\begin{array}{c}0.084 \\
(0.502)\end{array}$ & $\begin{array}{l}31.086 \\
(4.931)\end{array}$ & 0.969 \\
\hline
\end{tabular}

In table-8 an attempt has been made to assess the influence of DFL, Size of the organization and Investment on Average Cash Holding. In this study DFL has been taken as the measure of financial risk, log value of total assets has been taken as the measure of size of the organization and log value of total investment has been taken as the measure of Investment. The linear regression equation has been fitted in this study ACH $=b_{0}+b_{1}$ DFL $+b_{2}$ Size of the org. $+b_{3}$ Investment, $b_{0}$ is the value of intercept term (constant) and $b_{1}, b_{2}$ and $b_{3}$ are the slopes of the line, i.e. the regression coefficient of ACH on DFL, Size of the organization and Investment. This regression equation has been tested by 't' test.

Among FMCG sector Table 8 shows that for one unit increase in DFL the ACH of Britannia go down by 11.814 units which is statistically significant at $1 \%$ level. The other results indicate that for one unit increase in size of the organization the ACH of Britannia stepped up by 3.104 units which is statistically significant at 10\% level. From Table 8 it is found that for one in it increase in Investment the ACH of Britannia decreased by 0.093 units which is insignificant. It indicates that only the influence of size of the organization on ACH is positive whereas the influence of DFL and Investment on ACH in Britannia 
is negative. The coefficient of determination $\left(\mathrm{R}^{2}\right)$ makes it clear that only $79.2 \%$ of the variation of the company's ACH is accounted for by the variation in DFL, Size of Org and Investment.

From Table 8 it is found that for one unit increase in DFL the ACH of Dabur stepped down by 3.589 units which is statistically significant at $5 \%$ level. Table 8 also portrays that for one unit increase in size of the organization the ACH of Dabur go up by 2.761 units which is highly statistically significant at $1 \%$ level. Table 8 shows that for one unit increase in Investment the ACH of Dabur stepped down by 1.287 units which is statistically significant at $5 \%$ level. It implies that the influence of DFL and Investment on ACH in Dabur is negative whereas the influence of Size of the organization on ACH is negative. The coefficient of determination $\left(\mathrm{R}^{2}\right)$ makes it clear that only $91.5 \%$ of the variation of the company’s ACH is accounted for by the variation in DFL, Size of Org and Investment.

Table 8 reveals that for one unit increase in DFL, the ACH of HUL go down by 2.191 units, which is insignificant. Table 8 shows that for one unit increase in size of the organization, the ACH of HUL go up by 1.406 units which is statistically significant at $10 \%$ level. Table 8 also portrays that for one unit increase in Investment the ACH of HUL decreased by 0.478 units which is insignificant. It signifies that only the influence of Size of the organization on ACH in HUL is positive whereas the influence of DFL and Investment on ACH is negative. The coefficient of determination $\left(\mathrm{R}^{2}\right)$ makes it clear that only $43 \%$ of the variation of the company's ACH is accounted for by the variation in DFL, Size of Org and Investment.

It is found from Table 8 that for one unit increase in DFL the ACH Marico goes up by 1.342 units which is insignificant. Table 8 also reveals that for one unit increase in size of the organization the $\mathrm{ACH}$ of Marico go down by 0.584 units which is statistically significant at $10 \%$ level. Table 8 also reveals that for one unit increase in Investment the ACH of Marico stepped up by 0.314 units which is statistically significant at 5\% level. From this analysis it is clear that DFL and Investment of Marico positively influenced the ACH whereas the influence of size of the organization on ACH is negative. The coefficient of determination $\left(\mathrm{R}^{2}\right)$ makes it clear that only $66.8 \%$ of the variation of the company's $\mathrm{ACH}$ is accounted for by the variation in DFL, Size of Org and Investment.

Table 8 exhibits that for one unit increase in DFL, the ACH of Nestle goes down heavily by 32.854 units, which is statistically significant at $1 \%$ level. Table 8 also exhibits that for one unit increase in size of the organization the ACH of Nestle stepped up by 1.455 units which is statistically significant at $1 \%$ level. Table 8 also portrays that for one unit increase in Investment the ACH of Nestle go up by 0.084 units, it also statistically not significant. It signifies that the influence of Size of the organization and Investment on ACH in Nestle is positive whereas the influence of DFL on ACH in Nestle is negative. The coefficient of determination $\left(\mathrm{R}^{2}\right)$ makes it clear that only $96.9 \%$ of the variation of the company's ACH is accounted for by the variation in DFL, Size of Org and Investment. Thus, all the factors are influenced the ACH of each company in FMCG sector either positively or negatively depending upon the situation. But, the most interesting factor is that in most of the cases only size of the organization influence the ACH of each company positively, are highly statistically significant.

\section{Conclusion}

Management of current assets and current liabilities is popularly known as liquidity management. Its main objective is to maintain current assets in such a way so that it can meet the current liabilities timely. External financing can be the solution for payment of current liabilities but it is difficult to collect such financing even for a small and medium size organizations. At this point proper cash conversion cycle can minimizes the requirement of external borrowing as well as holding excess cash. 
Cash Conversion Cycle is such a useful technique by which we can easily and quickly assess the liquidity of the organization. It is a dynamic measure of continuous liquidity management with the help of Balance sheet and income statement data with time dimension.

A decision relating to holding cash is another important factor in liquidity management. Some organizations hold more cash and some organizations hold less. For that they framed different policies. In holding cash, cash conversion cycle may play a very vital role. In this study we give emphasis on such factors.

On the basis of CCC, HUL is exceptional and it followed by Nestle, Britannia, Dabur etc. From the correlation point of view, HUL and Marico registered a negative association between CCC and ITR. On the other hand Britannia and Marico registered a negative relationship between CCC and DTR.

From average cash holding point of view HUL is best but in case of Marico the average cash holding is poorer. Lower CCC may be the reason for holding excess cash of HUL. We all know that holding excess cash signifies lower profitability. In case of Marico it is observed that may be due to higher CCC the company maintained lower level of cash.

\section{References}

Baskin, J. B., \& Miranti Jr, P. J. (1999). A history of corporate finance. Cambridge University Press.

Bodie, Z., \& Merton, R. C. (2002). International pension swaps. Journal of Pensions Economics \& Finance, 1(01), 77-83.

Chiou, J. R., Cheng, L., \& Wu, H. W. (2006). The determinants of working capital management. Journal of American Academy of Business, 10(1), 149-155.

Deloof, M., \& Jegers, M. (1999). Trade credit, corporate groups, and the financing of Belgian firms. Journal of Business Finance \& Accounting, 26(7-8), 945-966.

Dittmar, A., \& Mahrt-Smith, J. (2007). Corporate governance and the value of cash holdings. Journal of Financial Economics, 83(3), 599-634.

Dittmar, R. F. (2002). Nonlinear pricing kernels, kurtosis preference, and evidence from the cross section of equity returns. Journal of Finance, 369-403.

Eljelly, A. M. (2004). Liquidity-profitability tradeoff: an empirical investigation in an emerging market. International Journal of Commerce and Management,14(2), 48-61.

Farris II, M. T., Hutchison, P. D., \& Hasty, R. W. (2011). Using cash-to-cash to benchmark service industry performance. Journal of Applied Business Research (JABR), 21(2).

Ferreira, M. A., \& Vilela, A. S. (2004). Why do firms hold cash? Evidence from EMU countries. European Financial Management, 10(2), 295-319.

Guney, Y., Ozkan, A., \& Ozkan, N. (2003). Additional international evidence on corporate cash holdings.

Holstrom, M. M. (1994). Evaluation of the geography component of K-12 teacher education in Santa Clara County, California.

Hutchison, P. D., Farris, M. T., \& Anders, S. B. (2007). Cash-to-cash analysis and management. CPA journal, 77(8), 42.

Jordan, J., Lowe, J. Taylor, P. “Strategy and Financial Policy in UK small Firms” Journal of Business Finance and Accounting 1998.

Kalcheva, I., \& Lins, K. V. (2007). International evidence on cash holdings and expected managerial agency problems. Review of Financial Studies, 20(4), 1087-1112.

Keown, A. J. (2003). Foundations of finance: The logic and practice of financial management.

Kim, C-S, D.C. Mauer, and A. E. Sherman, 1998, "The Determinants of Corporate liquidity: Theory and Evidence,” Journal of Financial and Quantitative Analysis 33: 305-334.

Moss, J. D., \& Stine, B. (1993). Cash conversion cycle and firm size: a study of retail firms. Managerial Finance, 19(8), 25-34. 
Myers, S. C. (1977). Determinants of corporate borrowing. Journal of financial economics, 5(2), 147175.

Myers, S. C., \& Majluf, N. S. (1984). Corporate financing and investment decisions when firms have information that investors do not have. Journal of financial economics, 13(2), 187-221.

Opler, T., Pinkowitz, L., Stulz, R., \& Williamson, R. (1999). The determinants and implications of corporate cash holdings. Journal of financial economics,52(1), 3-46.

Özbayrak, M., \& Akgün, M. (2006). The effects of manufacturing control strategies on the cash conversion cycle in manufacturing systems.International Journal of Production Economics, 103(2), 535-550.

Padachi, K. (2006). Trends in working capital management and its impact on firms' performance: an analysis of Mauritian small manufacturing firms.International Review of business research papers, 2(2), 45-58.

Richards, V. D., \& Laughlin, E. J. (1980). A cash conversion cycle approach to liquidity analysis. Financial management, 32-38.

Saccurato, F. (1994). The study of working capital. Business Credit, 96(1), 36-37.

Saddour, K. (2006). The determinants and the value of cash holdings: Evidence from French firms. Cahier de recherche $n, 6$.

Stickney, C.P. (1993). Financial Statement Analysis. A Strategic Perspective. $2^{\text {nd }}$. ed. The Dryden Press.

San-Jose, L., Iturralde, T., \& Maseda, A. (2008). Treasury management versus cash management. Available at SSRN 1088015. 